\title{
Rövid európai kitekintés: szemelvények a fogyatékossággal élő személyek jogairól az EU tagállamaiban a nemzetközi fórumok kritikáinak tükrében
}

\section{Dr. Lovászy László Gábor \\ https://doi.org/10.47707/Kulugvi_Szemle.2021.2.010}

2021. március 3-án adta ki az Európai Bizottság a következő tíz évre szóló, 2021-2030-as stratégiáját a fogyatékossággal élők jogairól (Union of Equality: Strategy for the Rights of Persons with Disabilities 2021-2030). ${ }^{1}$ Ennek kapcsán az alábbiakban visszatekintünk az elmúlt fél évtizedre: milyen jogesetek fordultak elő a fogyatékossággal élő európai polgárok vonatkozásában, milyen joggyakorlatot alakított ki az Európai Unió luxemburgi bírósága valamint az Európa Tanács égisze alatt múködő, strasbourgi emberi jogi bíróság. Elemzésünk indokolt esetben - röviden kitér még az USA Külügyminisztériuma által rendszeresen kiadott emberi jogi jelentések fogyatékossággal összefüggő, releváns megállapításaira, mint ahogy az ENSZ emberi jogi főbiztosának idevágó jelentéseire is, amikor a viszonyok és a körülmények részletesebb ismeretéhez ez szüikséges a jelen írás gondolatmenetében.

A különböző emberi jogi bírói fórumok ítéletei, illetve az ENSZ és az USA által kiadott országjelentések által megfogalmazott kritikák áttekintésének a célja - főszabályként - az elmúlt öt évben, de legfeljebb az elôző fogyatékosságügyi stratégia (European Disability Strategy 2010-2020: A Renewed Commitment to a Barrier-Free Euro$p e)^{2}$ kezdőévéig (2010) visszamenőleg hozott, legfrissebb, legfontosabb és legrelevánsabb ítéletek és megállapítások számbavétele az

$\underline{\text { https://ec.europa.eu/social/main.jsp?langld=en\&catld=1137\&furtherNews=ves\&ne }}$ wsld $=9938$

2 https://eur-lex.europa.eu/LexUriServ/LexUriServ.do?uri=COM:2010:0636:FIN:en:PDF 
egyes tagállamok vonatkozásában, méghozzá tagállamonként, abc-sorrendben haladva. Néhány tagállam esetében - az ügyek súlyosságára figyelemmel - még ettől az időbeli korláttól is eltekintünk. Nem szándékunk az ismertetett ítéletek és kritikák minősítése, rendszerezése, mint ahogy az sem, hogy azokból akár jogi, akár jogalkalmazói következtetéseket vonjunk le.

Néhány tagállam (pl. Hollandia, Ciprus, Észtország, Olaszor szág) a jelentősebb „hiányzó” jogi precedensek, valamint az emberi jogi elmarasztalások hiánya miatt nem kerüilt küiön kiemelésre, mint ahogy Magyarország sem került feldolgozásra, mert egyrészt az elemzés kitekintő jellege miatt nem volt szándék a magyar helyzet bemutatására, illetve a szerző mint az ENSZ fogyatékossággal élő személyek jogaival foglalkozó emberi jogi bizottság (UNCRPD Committee, továbbiakban: CRPD) 2013 és 2021 között mandátummal rendelkező, az ENSZ Közgyűlése által kétszer is titkosan, magas szavazatarányban megválasztott szakértője - az érvényes ösz szeférhetetlenségi szabályoknak megfelelően - nem vehetett részt a magyar esetek és következtetések (concluding observations) megvitatásban és elfogadásában sem.

Az EU-tagállamokban történt jogesetek rövid, mintegy kézi könyvszerú ismertetése tanulságul, a konkrét esetek pedig referenciaként szolgálhatnak kifejezetten a hazai jogászok és kutatók számára a tágabb európai uniós és emberi jogi bíráskodás gyakorlatának szélesebb körú áttekintése során.

Belgium esetében az Emberi Jogok Európai Bírósága (továbbiakban: EJEB) ítéletei szerint a mentális sérüléssel küzdők a fogva tartás alatt nem részesülnek a betegségüknek megfelelő ellátásban. ${ }^{3}$ Az itélet meghozatalát követően két évvel, 2015-ben az ENSZ emberi jogi főbiztosa aggályosnak tartotta, hogy a testi fenyítés alkalmazását nem tiltották be teljeskörủen, és Belgiumban a legfejlettebb országok körében az egyik legmagasabb volt az intézetekben elhelyezett fogyatékos gyermekek aránya. (Erre a problémára

3 L.B.-ügy, kérelemszám: /22831/8/; ítélet: 02.01.2013. 


\section{Külïgyi Szemle}

Hollandia esetében is felhívta a figyelmet az ENSZ emberi jogi fó biztosának Hollandiával foglalkozó jelentése, ${ }^{4}$ megemlítve azt is, hogy az örökbefogadás intézménye nem elterjedt, és a nevelőszülők száma is alacsony Hollandiában.) Ami pedig a szélesebb körủ akadálymentesítést illeti, az USA 2018-as Emberi Jogi Jelentése szóvá teszi, hogy a belga kormány csak az 1970 után épült épületek esetében indított akadálymentesítési programot. Az amerikai jelentés azt is hozzáteszi, hogy a fogyatékkal élő személyek aka dálymentes elhelyezésének biztosítása a börtönökben nem mindenhol biztosított.

Bulgária tekintetében az intézetben elhelyezett gyermekek sorsa szintén kiemelt téma volt az ENSZ emberi jogi főbiztosánál, aki szerint súlyos kihívások adódtak 2000 és 2010 között, mert a beszámolók szerint 238, intézetben elhelyezett gyermek hunyt el ezen időszak alatt, és ezeknek a haláleseteknek nem volt semmilyen büntetôjogi vagy más következménye.5 A balkáni ország esetében precedenst teremtett ugyanakkor az Európai Unió Bíróságának a Milkova-ügyben ${ }^{6}$ hozott ítélete, amely szerint a foglalkoztatás és a munkavégzés során alkalmazott egyenlő bánásmód általános kereteinek létrehozásáról szóló, 2000. november 27i 2000/78/EK tanácsi irányelv, valamint a fogyatékossággal élő személyek jogairól szóló ENSZegyezmény (továbbiakban: CRPDegyezmény) és az Unió Alapjogi Chartája alapján nem ellentétes az uniós joggal egy olyan nemzeti előírás, amely bár bizonyos fogyatékossággal élő munkavállalók számára elbocsátás esetén különleges előzetes védelmet biztosít általában, de nem biztosít ilyen védelmet

4 Report of the Office of the United Nations High Commissioner for Human Rights (A/HRC/WG.6/27/NLD/2), 24/12/2017

5 Compilation prepared by the Office of the United Nations High Commissioner for Human Rights in accordance with paragraph 15 (b) of the annex to Human Rights Council resolution $5 / 1$ and paragraph 5 of the annex to Council resolution 16/21 (A/HRC/WG.6/22/BGR/2), 23/02/2015.

6 C-406/15. számú ügy: Petya Milkova kontra Izpalnitelen direktor na Agentsiata za privatizatsia i sledprivatizatsionen kontrol, ECLI:EU:C:2017:198. 
az ugyanazon fogyatékossággal élő köztisztviselők számára, kivéve ha megállapítható az egyenlő bánásmód elvének sérelme, amelynek vizsgálata a kérdést előterjesztő bíróság feladata.

Bár Csehország esetében az elmúlt fél évtized vonatkozásában nem emelhetô ki jelentôsebb jogeset a témában, azonban a D.H. és mások ügyében ${ }^{7}$ az EJEB még 2006-ban hozott egy olyan ítéletet, amely esetében azóta sem sikerült maradéktalanul felszámolni a benne említett és elmarasztalt gyakorlatot. Az ENSZ emberi jogi főbiztosának 2017-es összefoglalója ${ }^{8}$ szerint súlyosan jogsértő az, hogy a roma gyermekeket gyakran sajátos nevelési igényűnek minősítik az oktatásban. Az emberi jogi biztos szerint 2017-ben úgy látta, hogy jelentős problémát jelent az is, hogy gyakorlat a pszichiátriai betegek ágyhoz kötözése egyes intézményekben, illetve a mechanikus és kémiai kényszerítő eszközök használata is tetten érhető értelmi sérült személyek kezelésekor.

Dánia esetében az Európai Unió Bírósága a Kaltoft-ügyben9 megállapította, hogy bár az uniós jog nem mondja ki általános elvként önmagában véve az elhízás alapján történő hátrányos megkülönböztetés tilalmát a foglalkoztatás és munkavégzés során, ugyanakkor lehetséges olyan körülmény, amely esetben már a CRPD-egyezménybe ütközik az ilyen megkülönböztetés. Amennyiben a munkavállaló elhízása „fogyatékosságnak” tekinthető, és ez az állapot olyan korlátozottsággal jár, amely küilönösen valamilyen hosszan tartó testi, szellemi vagy lelki ártalmon alapul, akkor korlátozhatja az adott személy teljes, hatékony és más munkavállalókkal egyenlő szerepvállalását a munkahelyén, és ezt a szempontot már figyelembe kell venni. Az ENSZ emberi jogi főbiztosa szerint 2015-ig Dánia nem fogadott

\footnotetext{
7 Kérelemszám: 57325/00, ítélet: 06/02/2006.

8 Report of the Office of the United Nations High Commissioner for Human Rights (A/HRC/WG.6/28/CZE/2), 4/09/2017.

9 C-354/13. számú ügy: Fag og Arbejde (FOA) kontra Kommunernes Landsforening (KL), ECLI:EU:C:2014:2463.
} 


\section{Külïgyi Szemle}

el átfogó antidiszkriminációs jogszabályt. ${ }^{10}$ Ennek kapcsán érdemes feleleveníteni, hogy az Európa Tanács mellett múködő Rasszizmus és Intolerancia Elleni Európai Bizottság (ECRI) 2017-ben kiadott dán országjelentése azért kritizálta az országot, mert az folyamatosan elutasította a csatlakozást az Emberi Jogok Európai Egyezménye (továbbiakban: EJEE) 12. jegyzőkönyvéhez." A hivatalos dán álláspont szerint a jegyzőkönyv elfogadása megkérdőjelezné a dán törvényhozás szuverenitását, és ezért nem csökkentené, hanem növelné a diszkrimináció veszélyét. ${ }^{2}$ Ezt megelôzően az ENSZ emberi jogi főbiztosának elóbb idézett jelentése azt állapította meg, hogy a nemzetközi szerződéseknek nines közvetlen hatálya a dán jogban, és ezt az Emberi Jogi Bizottság is aggályosnak tartotta, annak ellenére, hogy a dán Legfelső Bíróság is osztotta a dán állam álláspontját. Dánia esetében is kihívás az intézetben elhelyezett gyermekek magas száma, és a gyermekek egy jelentős része a létminimum alatti szinten él. Az emberi jogi főbiztos szerint az is aggályos, hogy nőtt a pszichostimuláns szerek alkalmazása a hiperaktív és figyelemzavaros gyermekek esetében. Ehhez kapcsolódva Dániát az ENSZ felszólította a fizikai, kémiai és egyéb kényszerített gyógyszeres kezelések beszüntetésére az intézményekben lakó fogyatékossággal élô emberek esetében. (Ennek előzményeként megemlíthető, hogy a gyermekmunka és annak legrosszabb formája, a gyermekprostitúció elleni fokozott küzdelemre már a Nemzetközi Munkaügyi Szervezet (ILO) 2012-ben kiadott országjelentése is felhívta Dánia figyelmét. ${ }^{13}$ )

10 Patrick Thornberry: The international convention on the elimination of all forms of racial discrimination. Oxford, Oxford University Press, 2016. 110; Compilation prepared by the Office of the United Nations High Commissioner for Human Rights in accordance with paragraph 15 (b) of the annex to Human Rights Council resolution $5 / 1$ and paragraph 5 of the annex to Council resolution 16/21. www.refworld.org.ru/pdfid/59519c924.pdf

11 https://rm.coe.int/fifth-report-on-denmark/16808b56a4

12 https://rm.coe.int/government-comments-on-the-fifth-report-ondenmark/16808b56ad

13 www.ilo.org/dvn/normlex/en/f?p=NOR.MLEXPUB:13100:0::NO::P13100_COMMENT $\underline{\text { ID:2700551 }}$ 
Finnország példája is érdekes esettel gazdagította az uniós tagállamok emberi jogi joggyakorlatát. Az EJEB 2017-ben nem támogatta, hanem elutasította egy értelmi sérült személy szabad mozgással kapcsolatos beadványát az A.-M.V.-ügyben, ${ }^{14}$ amikor a panaszos sérelmezte, hogy a finn bíróság nem engedélyezte gondnokának a leváltását, aki nem támogatta, hogy a gondnokolt egy kis, távoli faluba költözzön, távol a mostohaszüleitől. Az EJEB úgy látta, hogy a nemzeti bíróság az elutasító ítéletével nem sértette meg a panaszos jogait, mert az a panaszos érdekeit is figyelembe véve nem adott helyet a belátási képességében egyébként korlátozott ügyfél kérvényének.

Franciaország az autizmussal élő gyermekek és személyek vonatkozásában került a figyelem középpontjába az emberi jogi diskurzus során. Az ENSZ Gyermekjogi Bizottságának 2016-os jelentése szerint az autista gyermekek Franciaországban „széles körű jogsértéseknek vannak kitéve”. Jelentős részük nem jut hozzá az általános oktatáshoz és sokaknál, állítja a jelentés, „nem hatékony pszichoanalitikus terápiákat, túlgyógyszerezést és elhelyezést alkalmaznak a pszichiátriai kórházakban és intézményekben." ${ }^{5}$ Ilyen előzmények után az EJEB 2018 ban úgy döntött a Dupin-ügyben, ${ }^{16}$ hogy önmagában az autizmussal élő gyermeknek állami iskolákba történő felvételének elutasítása nem keletkeztet diszkriminációt, mert a gyermek állapota is befolyásolja az iskoláztatás körüilményeit. (Az ügy egyik leglényegesebb vonása az volt, hogy az érintett szülők közt is vita állt fenn, ugyanis az apa támogatta gyermekének speciális intézményben történő iskoláztatását, míg az anya elvetette azt.) Szintén a jogvédők ellenében hozott ítéletet az EJEB, amikor 2018-ban úgy határozott, hogy nem sértette meg Franciaország az EJEE-ét azzal, hogy nem biztosította (gondnoksági bíró által) a gondnokság alatt álló személy számára a korlátozásmentes jogot a

\footnotetext{
14 Kérelemszám: 53251/13, ítélet: 23/03/2017.

15 Report of the Office of the United Nations High Commissioner for Human Rights (A/H HRC) WG.6/29/FRA/2), 13/11/2017 és lásd különösen: CRC/C/FRA/CO/5, para. 57 (b) és 59. pontok.

16 Kérelemszám: 2282/17, itélet: 18/12/2018.
} 


\section{Külïgyi Szemle}

házasságkötésre a Delecolle-ügyben ${ }^{17}$ született döntés alapján. Ugyan akkor a belátási képességüikben nem korlátozott fogyatékos személyek esetében az EJEB még korábban, 2015 februárjában elmarasztalta az országot a Helhal-ïgyben ${ }^{18}$ amiatt, hogy megsértette egy olyan fogyatékossággal élő elítélt személy méltóságát, akinek megfelelő személyzet hiányában a rabtársa volt kénytelen segíteni tisztálkodni. Az ENSZ - egyebek mellett - felhívta Franciaországot arra is, hogy támogassa valamennyi fogyatékosságban szenvedô személy országos érdekvédelmét, mint ahogy a bentlakásos intézmények kiváltásának folyamatát is, valamint az elóbb említett célcsoport, az autizmussal élők helyze tének javítását is.

Görögország szintén a fogyatékkal élő gyermekek kapcsán került az érdeklődés homlokterébe: az ENSZ emberi jogi fóbiztosa azt állapítot ta meg 2016-ban, hogy a lechainai gyermekotthonban embertelen kö rülmények közt éltek a fogyatékossággal élő gyermekek, akiket ráadá sul gyógyszeresen szádaltalak, illetve az ágyakhoz szíjaztak. (A jelenség kapcsán két évvel később az USA 2018. évi Emberi Jogi Jelentése is súlyos problémának tartotta a gyermekekkel szembeni erôszakot. ${ }^{19}$ ) Az ENSZ emberi jogi főbiztosa azt is hozzátette, hogy a fogyatékossággal élő gyermekek mindössze $15 \%$-a járhat iskolába a beszámolók szerint. ${ }^{20}$

Horvátország esetében szintén előfordult egy fontos, a cselekvőké pességgel összefüggő jogügy az EJEB-nél. A Krušković-ügyben ${ }^{21}$ egy cselekvőképtelen személy saját gyermeke apjaként történő

17 Kérelemszám: 37646/13, itélet: 25/10/2018.

18 Kérelemszám: 10401/12, ítélet: 19/2/2015

19 https:/www.state.gov/wp-content/uploads/2019/03/GREECE-2O18-HUMAN RIGHTS-REPORT.pdf

20 Compilation prepared by the Office of the United Nations High Commissioner for Human Rights in accordance with paragraph 15 (b) of the annex to Human Rights Council resolution $5 / 1$ and paragraph 5 of the annex to Council resolution 16/21 (A/HRC/WG.6/25/GRC/2), 07/03/2016.

21 Kérelemszám: 46185/08, itélet: 21/09/2011. 
elismerésének, illetve nyilvántartásba vételének megtagadása volt a kérdés. Az EJEB egy másik, hasonló vonatkozású témában is elmarasztalta Horvátországot a Guberina-ügyben, ${ }^{22}$ mert a horvát hatóságok nem vették figyelembe egy fogyatékossággal élő gyermek apjának adókedvezményre vonatkozó kérelmét súlyosan fogyatékos gyermekének szükségleteihez - az észszerú alkalmazkodás követelményére is figyelemmel - igazodó ingatlanvásárlása kapcsán. A fogyatékos gyermekeknél maradva, több európai uniós tagállamhoz hasonlóan, az ENSZ emberi jogi főbiztosa szerint Horvátországban is aggályos volt, hogy a fogyatékossággal élő személyek körében túl magas az intézményben élő gyermekek száma (2016), és nem volt látható csökkenő tendencia ezen a téren. A főbiztos szerint az egyértelmú szabályozási környezet is hiányzott a fogyatékossággal élő gyermekek elhelyezése kapcsán. Ennek közvetlen előzményeként az ENSZ Kínzás Elleni Bizottsága 2015-ben aggályait fejezte ki a pszichiátriai intézményekben alkalmazott fizikai erőszak küilönböző formáit illetôen. $^{23}$

Írország is az intézetben elhelyezett személyek kapcsán került gór cső alá, ugyanis az ENSZ emberi jogi főbiztosa szerint Írországnak be kellene tiltania az erőszakos (nem beleegyezésen alapuló) gyógyszeres kezeléseket, az elektrosokk és más kényszerítő eszközök használatát. ${ }^{24}$ Egy 2018-ban megjelent, a Trinity College által publikált tanulmány szerint Írországban évente félszáz embert kezelnek

22 Kérelemszám: 23682/13, ítélet: 22/03/2016.

23 Compilation prepared by the Office of the United Nations High Commissioner for Human Rights in accordance with paragraph 15 (b) of the annex to Human Rights Council resolution 5/1 and paragraph 5 of the annex to Council resolution 16/21 (A/HRC/WG.6/22/HRV/2). 23/02/2015.

24 Compilation prepared by the Office of the United Nations High Commissioner for Human Rights in accordance with paragraph 15 (b) of the annex to Human Rights Council resolution 5/1 and paragraph 5 of the annex to Council resolution 16/21 (A/HRC/WG.6/25/IRL/2). 07/03/2016. 


\section{Külïgyi Szemle}

elektrosokkal akaratuk ellenére. ${ }^{25}$ Ugyanebben az évben jogszabály által létrehozott hivatalos szerv, a Mental Health Commission által lefolytatott hivatalos vizsgálat azt állapította meg, hogy az érintettek egyötödének az emberi méltóságát sem tartották tiszteletben az ilyen intézményekben, mert a vizsgált intézményekben élök 43\%-a számára nem biztosított az egyágyas szoba, valamint a megosztott szobákban élők 90\%-ának nem volt semmilyen privát szférája, olyannyira, hogy még függöny sem választotta el az ágyaikat. ${ }^{26}$

Lengyelország egy érdekes esettel hívta fel magára a figyelmet: a Kacper Nowakowski-ügy ${ }^{27}$ során az EJEB 2017 januárjában úgy döntött, hogy az érintett siketnéma apának megvan a joga ahhoz, hogy a hallássérült fiúgyermekével jelnyelven tarthasson kapcsolatot, és a nemzeti bíróságnak nem csupán az érintett fogyatékosságának fiziológiai tényére, hanem a lehetséges akadálymentesítési megoldásokra is figyelemmel kellett volna lennie.

Lettországot - Írországhoz hasonlóan - az állami fenntartású szociális intézményekben élő felnőtt értelmi sérültekkel szembeni bánásmód miatt marasztalták el. Az ENSZ Kínzás Elleni Bizottsága aggályait fejezte ki azon lett gyakorlat miatt, amikor felnőtt értelmi sérültteket erôszakkal szádaltak erős gyógyszerekkel, és hiányoztak a megfelelő garanciális szabályok a visszaélések megakadályozására, valamint a panaszok kivizsgálására. ${ }^{28}$

25 https://www.independent.ie/irish-news/health/electric-shock-therapypositive-37062418.html

26 https://static.rasset.ie/documents/news/2019/07/8592-mhc-2018-inspection24hr-3.pdf

27 Kérelemszám: 32407/13, ítélet: 17/01/2017.

$28 \mathrm{CAT} / \mathrm{C} / \mathrm{LVA} / \mathrm{CO} / 3-5$. https://undocs.org/CAT/C/LVA/CO/3-5 és lásd még: Compilation prepared by the Office of the United Nations High Commissioner for Human Rights in accordance with paragraph 15 (b) of the annex to Human Rights Council resolution $5 / 1$ and paragraph 5 of the annex to Council resolution 16/21 (A/HRC/WG.6/24/LVA/2), 18/11/2015 
Litvánia is a belátási képességüikben korlátozott személyek kapcsán került az EJEB elé. Az A.N.-ügyben ${ }^{29}$ 2016-ban hozott döntés szerint a litván gondnoksági rendszer kapcsán a taláros testület jogsértő nek találta azt a szabályozást és gyakorlatot, miszerint az érintett, súlyos mentális sérüléssel rendelkező személy nem kérvényezheti szabadon a saját cselekvőképtelenségének felülvizsgálatát, megsértve az EJEE 6. cikkét. Ráadásul az ENSZ fogyatékkal élő személyek jogaival foglalkozó bizottsága (CRPD) szerint ${ }^{30}$ Litvániának biztosítania kell a hozzáférhetỏ és akadálymentesített jogi képviseletet a fogyatékkal élő személyek számára a szabadságot korlá tozó intézményekben is, különös tekintettel a börtönökre. Egy másik témában - de nem egyedülálló módon - 2016-ban az ENSZ emberi jogi főbiztosa egy kellő költségvetési támogatásra támaszkodó, átfogó intézménykiváltási program elindítását is javasolta, méghozzá egy megfelelő monitoringrendszer kiépítésével együtt. A főbiztos ugyanis aggályosnak látta a fogyatékkal élő gyermekek, különösen az értelmi sérült gyermekek elhelyezését a bentlakásos, illetve nappali intéz ményekben, különösen a ventai intézményben. A főbiztos hozzátette azt is, hogy a beleegyezésen nem alapuló gyógykezelés alkalmazása kapcsán is hiányoznak a megfelelő jogi garanciák. ${ }^{31}$

Luxemburg - Belgiumhoz és Hollandiához hasonlóan - kritikák kereszttüzében áll az intézményekben elhelyezett fogyatékkal élő személyek kapcsán. Az emberi jogi főbiztos 2017-es jelentésében megjegyezte, hogy folyamatosan nőtt a sérült emberek intézményi formában történő elhelyezésének kockázata. Ráadásul a fơbiztos szerint a fogyatékossággal élő személyek jogainak érvényesülését monitorozó intézmények (Consultative Council of Human Rights és

\footnotetext{
29 Kérelemszám: 17280/08, ítélet: 31/05/2016.

30 Lásd különösen: CRPD/C/LTU/CO/1 28. pont.

31 Compilation prepared by the Office of the United Nations High Commissioner for Human Rights in accordance with paragraph 15 (b) of the annex to Human Rights Council resolution 5/1 and paragraph 5 of the annex to Council resolution 16/21 (A HRC/WG.6/26/LTU/2), 22/08/2016.
} 


\section{Külïgyi Szemle}

Center for Equal Treatment) vonatkozásában hiányzik a hatékony és megfelelő hatáskör a diszkriminációs panaszok érdemi kezelésére. Ezen túlmenően a főbiztos kifejezetten szegregációként azonosította az oktatás területén a fogyatékossággal élő gyermekek esetében, különösen az értelmi sérült gyermekek esetében követett luxemburgi gyakorlatot. Az ENSZ emberi jogi fóbiztosa aggályosnak tartotta azt a luxemburgi gyakorlatot is, miszerint a pszichiátriai intézményben élő, értelmileg sérült fogyatékos emberek esetében fizikai erőszakot alkalmaznak, ami kínzásnak minôsülhet. ${ }^{32}$

Málta esetében általános jelleggel 2018-ban az ENSZ emberi jogi fóbiztosa arra mutatott rá jelentésében, hogy Málta még nem hozott létre egyértelmű és széles körű mandátummal rendelkező nemzeti emberi jogi intézményt az emberi jogok monitorozása érdekében. Ami pedig a politikai jogokat illeti, Málta esetében a föbiztos előbb idézett jelentésében azt is kiemelte, hogy néhány esetben vak és látássérült szavazóknak a választási bizottság politikai pártok által delegált tagjai előtt szóban kellett kifejezniük választói akaratukat, ami a választójog titkosságát sértette meg. ${ }^{33}$

Németország egy speciális esettel, a Surjit Singh Bedi-üggyel hívta fel magára a figyelmet a munkajog világában. Az uniós jogorvosla ti fórumon a fogyatékossággal élő munkavállalók helyzetét érintôen született európai bírósági ítélet, amely a 2000. november 27-i 2000/78/EK tanácsi irányelvvel ellentétesnek találta az olyan, kollektív szerződésben szereplő rendelkezéseket, amelyek előírják, hogy a munkahelyét elvesztett munkavállalónak, megfelelő megélhetése biztosításának céljából, a kötelező nyugdíjbiztosítási rendszer szerinti öregségi nyugdíjra való jogosultsága eléréséig

32 Report of the Office of the United Nations High Commissioner for Human Rights (A/HRC/WG.6/29/LUX/2), 13/11/2017.

33 Report of the Office of the United Nations High Commissioner for Human Rights (A/HRC/WG.6/31/MLT/2), 27/08/2018. 
járó átmeneti kiegészítő támogatás folyósítása megszűnik, amikor e munkavállaló teljesíti a súlyos fogyatékossággal élő személyek előrehozott öregségi nyugdíjhoz szükséges feltételeket. ${ }^{34}$

Ausztria esetében az osztrák rendvédelmi szervek munkájával kapcsolatban az ENSZ emberi jogi föbiztosa azt fogalmazta meg, hogy a börtönben fogvatartottakkal, illetve a pszichiátriai, fogyatékossággal élő betegekkel szemben túlzott, jogellenes erőszakot alkalmaznak. ${ }^{35} \mathrm{Az} \mathrm{EU}$ Alapjogi Ügynökségének (FRA) 2019-es tematikus jelentése (Criminal detention conditions in the European Union: rules and reality $)^{36}$ a fogva tartás körülményeinek vizsgálatáról azt emeli ki, hogy bár Ausztriában létezik egy úgynevezett Code of Conduct for Detention, azonban a szaniterhelyiségekben a magánszférához való jog megfelelő biztosításával kapcsolatban problémák állnak fenn. Nemcsak Ausztria, hanem Portugália esetében is aggasztónak tartja a helyi börtönviszonyokat az Európa Tanács Kínzás Elleni Bizottsága (CPT). Ezt az ENSZ emberi jogi főbiztosa is megemlítette 2014-es jelentésében. ${ }^{37}$ Nemcsak a 120\% körüli túlzsúfoltság, hanem a pszichiátriai kezelésre szoruló fogvatartottak nem megfelelő orvosi ellátása is aggályos volt a CPT szerint. Erre a FRA 2019-es tematikus, fentebb idézett jelentésében hivatkozott, miszerint 2016-ban a portugál adatok alapján a 48 börtönnek több mint fele, 28 küzdött túlzsúfoltsággal. Az ENSZ emberi jogi fóbiztos összefoglaló jelentése szerint továbbá aggályos az is,

34 C-312/17. számú. ügy: Surjit Singh Bedi kontra Bundesrepublik Deutschland és Bundesrepublik, ECLI:EU:C:2018:734.

35 Compilation prepared by the Office of the United Nations High Commissioner for Human Rights in accordance with paragraph 15 (b) of the annex to Human Rights Council resolution 5/1 and paragraph 5 of the annex to Council resolution 16/21 (A HRC/WG.6/23/AUT/2), 23/08/2015.

36 https://fra.europa.eu/sites/default/files/fra_uploads/fra-2019-criminal-detentionconditions-in-the-eu_en.pdf

37 Compilation prepared by the Office of the United Nations High Commissioner for Human Rights in accordance with paragraph 15 (b) of the annex to Human Rights Council resolution $5 / 1$ and paragraph 5 of the annex to Council resolution 16/21 (A HRC/WG.6/19/PRT/2). 13/02/2014. 


\section{Külïgyi Szemle}

hogy nem minden esetben vizsgálhatja meg, illetve kérdezheti ki az orvos a sérült elítéltet a sérüléseirỏl a börtönszemélyzet jelenléte nélkül. Ezzel kapcsolatban különösen nagy probléma a börtönökben elkövetett öngyilkosságok magas száma, valamint az is, hogy a 16 és 18 év közöttiekre már kiszabható akár 30 napos átmeneti magánzárka is.

Az EJEB által hozott ítéletek kapcsán Románia rendszeresen, több alkalommal is felhívta magára a nemzetközi szakmai és emberi jogi közösség figyelmét. ${ }^{38}$ Az ENSZ szerint 2011 januárja és 2014 augusztusa között Romániában közel 2000 fogyatékos sze mély veszthette életét a rossz ápolási körüilmények miatt. Civilek által eljuttatott jelentések, beszámolók szerint ${ }^{39}$ korábban, csak 2003-2004-ben a Poiana Mare nevú pszichiátriai kórházban közel száz személy veszthette életét. Az EJEB 2016 májusában elmarasztalta Romániát az I.C.- -ügyben ${ }^{40}$ egy 14 éves, fogyatékkal élő lány megerőszakolása ügyében, mert a bíróság szerint a hatóságok nem kellő mértékben vették figyelembe az áldozat beszámolóját, és ezzel az eljárással, vagyis az embertelen, megalázó bánásmód alapján megsértették az EJEE 3. cikkét. 2020-ban egy újabb, a Cîntaügyben ${ }^{41}$ született döntés a fogyatékkal élő személyek témájában: az EJEB egy értelmi sérült apa gyermeke láthatási jogának korlátozása miatt marasztalta el az országot, mert a román bíróság nem vizsgálta érdemben az apa sérülését gyermeke láthatósága kapcsán.

Spanyolország esetében is úgy látja a CRPD Bizottsága 2019-ben, ${ }^{42}$ hogy a spanyol polgári eljárási törvény (763. cikkely) és gyakorlat lehetôvé teszi a fizikai, mechanikus, gyógyszeres, elektrosokkos

38 Report of the Office of the United Nations High Commissioner for Human Rights (A/HRC/WG.6/29/ROU/2), 9/11/2017

39 https://fra.europa.eu/sites/default/files/fra_uploads/2160-mental-health-study2009-RO.pdf.

40 Kérelemszám: 36934/08, itélet: 24/5/2016.

41 Kérelemszám: 3891/19, ítélet: 18/2/2020.

42 Lásd különösen: CRPD/C/ESP/CO/2-3 29. pont.

Rövid európai kitekintés.. 
kényszerítő eszközök és terápiák alkalmazását, akár az érintett személy beleegyezése nélküil is. Az emberi jogi fóbiztos szerint mind a spanyol médiában, mind pedig a gyógyszeripar részéról folytatódik a pszichoszociális fogyatékossággal élő emberek megbélyegzése. A föbiztos szerint sürgősen intézkedéseket kell hozni Spanyolországban a fogyatékos gyermekek intézményekben történő elhelyezésének megakadályozása érdekében, megfelelő, közösségi alapú és a családokat támogató szolgáltatások fejlesztésével, illetve egy intézménykiváltási program biztosításával. ${ }^{43}$ Speciális jogesetként értelmezhető a Daouidi-ügy, ${ }^{44}$ amelyben az uniós taláros testület a munkahelyi balesetek témájában foglalkozott a fogyatékossággal összefüggésben a „hosszan tartó” jelleg meghatározásával. Ennek során CRPD rendelkezéseivel együtt értelmezte a bíróság ezt a kérdést. Itt említendő meg a Ruiz Conejero-ïgy is, ${ }^{45}$ amelynek alapján az uniós joggal ellentétesnek bizonyult az olyan nemzeti szabályozás, amely lehetővé teszi azt, hogy a munkáltató felmondhatja a munkavállaló munkaszerződését annak akár igazolt, de rendszeresen ismétlődő távollétei miatt olyan esetben is, amikor e távollétekre a munkavállaló fogyatékosságának betudható betegségek miatt kerüil sor, kivéve, ha e szabályok - amelyek a munkahelyi hiányzás elleni küzdelem törvényes célját szolgálják - nem lépik túl a szüikséges mértéket. Ez utóbbi megítélése az adott bíróság feladata. Egy még frissebb döntésében az uniós bíróság a Nobel Plastiques Ibérica SAügyben ${ }^{46}$ a fogyatékossággal kapcsolatosan azt nyilvánította ki, hogy az egy olyan egészségi állapot, amely küilönösen valamilyen tartósan fennálló testi, értelmi vagy lelki károsodáson alapuló korlátozottságot

43 Compilation prepared by the Office of the United Nations High Commissioner for Human Rights in accordance with paragraph 15 (b) of the annex to Human Rights Council resolution $5 / 1$ and paragraph 5 of the annex to Council resolution 16/21 (A/HRC/WG.6/21/ESP/2), 11/11/2014.

44 C-395/15 számú ügy: Mohamed Daouidi kontra Bootes Plus SL és társai, ECLI:EU:C:2016:917.

45 C-270/16 számú ügy: Carlos Enrique Ruiz Conejero kontra Ferroser Servicios Auxiliares SA és Ministerio Fiscal, ECLI:EU:C:2018:17.

46 C-397/18 számú ügy: DW kontra Nobel Plastiques Ibérica SA. ECLI:EU:C:2019:703. 


\section{Külïgyi Szemle}

eredményez, és amely más egyéb akadállyal együtt korlátozhatja az érintett személy szakmai életben való teljes, hatékony és más munkavállalókkal egyenlő részvételét. (Az ítélet érinti az úgynevezett észszerű alkalmazkodás (reasonable accommodation) követelményét is, amit a munkáltatónak biztosítania kell.)

Svédország esetében az ENSZ emberi jogi főbiztosa 2014-es jelentésében szintén az önveszélyes, pszichoszociális állapotuk miatt akaratuk ellenére zárt intézményekbe kerülő személyek elektrosokkterápiájának kötelező alkalmazására hívta fel a figyelmet, küiönös tekintettel a nók esetében, valamint a fogyatékosággal élő személyek körében kiugró arányban mutatkozó öngyilkosságokra. ${ }^{47}$ Az ENSZ emberi jogi fóbiztosa már 2014-ben arra mutatott rá, hogy az értelmi fogyatékos gyermekekkel erőszakosan bánnak a részükre fenntartott egészségügyi intézményekben, bizonyos esetekben ágyhoz kötözve és magánzárkákban tartva őket.

Szlovákia is hasonló témában kapott 2018-ban elmarasztalást az ENSZ emberi jogi fóbiztostól: a fogyatékossággal élő személyek esetében az a gyakorlat, hogy a gondnok jellemzően a gondnokolt megfelelő tájékoztatása nélkül adja meg az orvosi kezelésekhez való hozzájárulást, valamint a fizikai, kémiai és egyéb kényszerített gyógyszeres kezelések az intézményekben lakó fogyatékossággal élő emberek esetében még mindig létező gyakorlat. ${ }^{48}$

Végezetül Szlovénia esetében az ENSZ Gyermekjogi Bizottságának (CRC) korábbi, 2013-as értékelése szerint a szlovéniai gyermekek pszichikai egészsége és mentális állapota aggodalomra adott

47 Compilation prepared by the Office of the United Nations High Commissioner for Human Rights in accordance with paragraph 15 (b) of the annex to Human Rights Council resolution 5/1 and paragraph 5 of the annex to Council resolution 16/21 (A) HRC/WG.6/21/SWE/2), 12/11/2014

48 Report of the Office of the United Nations High Commissioner for Human Rights (A/HRC/WG.6/32/SVK/2), 6/11/2018 
okot. ${ }^{49}$ A CRC Bizottság jelentésében azt állította, hogy a 10-14 éves korosztály körében az öngyilkosság a második leggyakoribb halálok az országban. Az emberi jogi fóbiztos 2019. évi jelentésé ben azt is szüikségesnek tartotta, hogy a pszichiátriai intézetek ben elhelyezett személyek helyzetének bírósági monitoringját is biztosítsák, méghozzá megfelelő jogi garanciák biztosításával. ${ }^{50}$

A legfontosabb esetjog és kritikák rövid áttekintése után kijelenthető, hogy már önmagában ezeknek az eseteknek a rövid felsorolása is megmutatja azt, hogy bár nincs két egyforma tagállam, nines két azonos életviszony és gyakorlat az uniós tagállamokban, ami egyúttal azok sokszínúségét és fejlettségbeli el téréseit mutatja, néhány „ügytípus” tekintetében azonban igenis vannak hasonló problémák és kihívások (gondokság, börtönviszonyok, bentlakásos intézmények, gyógykezelés). Mindazonáltal ezen esetek szélesebb körủ értelmezéséhez egy tágabb összefüggésrendszer is szükségeltetik, hiszen ezeknek az eseteknek van egy tágabb társadalmi, szociális kontextusa is, ami nem nélkülöz hetô a tisztább és pontosabb kép kialakítása érdekében.

A teljesebb kép, vagyis a még több „ügytípus”, mint például a foglalkoztatás, munkanélküliség, akadálymentesítés vagy éppen a közszolgáltatásokhoz való hozzáférés stb. érdekében ajánlható - a Külgazdasági és Külüigyminisztérium szakmai segítségével is készült - Európai körkép - Európai értékek és megvalósulásuk az Európai Unió tagállamaiban az adatok és számok tükrében címú, Trócsányi László és Lovászy László Gábor szerkesztésében megjelent kötet, amelyet a Ludovika kiadó gondozott és jelentetett meg 2020 végén. Jelen írás is ezen kiadványon alapul, így további jogesetekről és helyzetértékelésekről az Európai körképből tudhat meg többet a tisztelt Olvasó.

49 https://undocs.org/CRC/C/SVN/CO/3-4.

50 Compilation prepared by the Office of the United Nations High Commissioner for Human Rights in accordance with paragraph 15 (b) of the annex to Human Rights Council resolution 5/1 and paragraph 5 of the annex to Council resolution 16/21 (A/HRC/WG.6/20/SVN/2), 18/08/2014. 